\title{
Circumstantial evidence for the presence of monk seals in the West Indies
}

\author{
I. L. Boyd and M. P. Stanfield
}

Based on interviews with 93 fishermen in northern Haiti and Jamaica during 1997 an assessment was made of the likelihood that monk seals survive in this region of the West Indies. Fishermen were asked to select marine species known to them from randomly arranged pictures: 22.6 per cent $(\mathrm{n}=21)$ selected monk seals. This number was significantly ( $\mathrm{P}<0.001)$ greater than the number who selected control species (walrus, harbour seal, and sea-lion) that they were unlikely to have observed. However, it was not significantly different $(\mathrm{n}=19, \mathrm{P}>0.1)$ from the number who selected manatees, which are known to occur in the region in small numbers. More than 95 per cent of respondents also identified species that are known to occur commonly in the region. Further questioning of the 21 respondents who selected monk seals suggested that 16 (78 per cent) of them had seen at least one in the past 1-2 years. Those fishermen that were able to provide further descriptions gave information about size and colour that was consistent with many of these seals being monk seals. It is possible that the Caribbean monk seal is not extinct.

\section{Introduction}

The Caribbean or West Indian monk seal Monachus tropicalis has been classified as possibly extinct under the criteria used by the International Union for the Conservation of Nature (IUCN, 1996; Reijnders et al., 1993). There have been no confirmed sightings of the species since 1952 (Rice, 1973). An unconfirmed report of a single individual on an offshore island in northern Haiti in 1985 led to an investigation of this region sponsored by the US Marine Mammal Commission (Woods and Hermanson, 1987). Although little further evidence was obtained to support the view that monk seals survived in the West Indies, the authors concluded that it was too early to be certain that the species was extinct. Three previous surveys (Kenyon, 1977, Nichols et al., 1980, LeBoeuf et al., 1986) in recent years have also produced no evidence of monk seals. Using a statistical analysis of the frequency of past sightings, Solow (1993) suggested that the probability of the Caribbean monk seal surviving at the time of publication of his paper was only 0.053 . However, he used only 'reliable' reports from the scientific literature. The Caribbean monk seal has rarely been seen since it was first described in 1850 , but intermittent sightings have occurred over more than a century (King, 1956; Rice, 1973).

The last confirmed sighting of a monk seal in the Caribbean was at the Serranilla Bank (Rice, 1973), an area of cays that is rich in beach habitat. The unconfirmed sighting in 1985 also occurred on a beach (Woods and Hermanson, 1987). This suggests that beach habitat was important to the Caribbean monk seal and much of the past survey effort has targeted locations with suitable beaches (Kenyon, 1977; LeBoeuf et al., 1986). However, the presence of man at sites visited (Kenyon, 1977) gave little confidence that seals could exist there unmolested.

This paper reports the results of a survey carried out in the West Indies in 1997. From the outset, it was appreciated that the chances of a survey team seeing a monk seal, even if it

() $1998 \mathrm{FFI}$, Oryx, 32 (4), 310-316 
was extant, were remote. Therefore, emphasis was placed on questioning local inhabitants on the principle that, if seals are present in the region, they will be most likely to have seen them.

\section{Materials and Methods}

The survey was conducted from the sailing vessel Janetta Emily, a 13.4-m ketch. The vessel was deployed in the West Indies during February and March 1997. Before this, the vessel had spent two winter seasons (January-May 1995; November 1995-April 1996) cruising in the Caribbean. These cruises had covered coastal regions from Lesser Antilles to northern Cuba. Residents of the locations, including coastal fishing villages, that were visited were questioned informally and shown photographs of Hawaiian monk seals and of several other species, including the

Table 1. Locations in Jamaica and Haiti in which fishermen were questioned about animals they had seen

\begin{tabular}{lrl}
\hline & & No. \\
Location & $\begin{array}{l}\text { No. } \\
\text { interviewed }\end{array}$ & $\begin{array}{l}\text { identifying } \\
\text { seals }\end{array}$ \\
\hline N.E. Jamaica & & \\
Port Antonio & 5 & 0 \\
Panton's Hope & 2 & 0 \\
Rural Hill & 1 & 1 \\
Robin's Bay & 1 & 0 \\
Manchioneal & 16 & 1 \\
Long Bay & 1 & 0 \\
N. Haiti & & \\
Môle St Nicolas & 8 & 4 \\
$\quad$ (main port) & & \\
Carnage (Môle) & 4 & 1 \\
La Presquil (Môle) & 6 & 1 \\
Baie du Port Ecu & 14 & 4 \\
Port de Paix & 5 & 0 \\
Ile de la Tortue & & \\
Port Vincent & 5 & 3 \\
Basse Terre & 13 & 7 \\
Cayenne & 4 & 1 \\
Pointe aux Oiseaux & 3 & 1 \\
Tête Ligne & 5 & 1 \\
\hline
\end{tabular}

California sea-lion Zalophus californianus. During these cruises the only area where local inhabitants indicated that seals had been seen was in northern Haiti.

In 1997, a formal questionnaire was used to estimate the proportion of fishermen in northeast Jamaica and northern Haiti who had seen an animal looking like a monk seal in recent years (Table 1). The aim was to interview only fishermen and estimate the probability that they had seen monk seals. Based on their experience of the animals they have encountered, these fishermen were asked to select pictures of animals they had seen from a group of nine pictures. The colour pictures (taken from illustrations in Waller, 1996) were mounted on stiff card like jigsaw pieces. Each measured $4-6 \mathrm{~cm}$ long and $2-4 \mathrm{~cm}$ broad and they were cut out in the shape of the outline of the animal concerned. All the pictures were placed face up on a board, arranged randomly by mixing them as one might mix dominoes, and presented to the interviewee. The pictures were (1) manatee, (2) walrus, (3) Mediterranean monk seal, (4) harbour seal, (5) sea-lion, (6) dolphin, (7) shark, (8) barracuda, (9) sea turtle. The picture of the monk seal illustrated an animal with a creamy-white belly. The interviews were carried out as follows:

Q1. Are you a fisherman?

If the answer was yes,

We are interested to know what animals you see while you are fishing.

Q2. Could you please pick out the animals you have seen?

The respondent was then presented with the board of pictures. The order in which he selected the pictures from the board was recorded. When a picture was selected, it was set to one side. If the interviewee picked out the monk seal, harbour seal or the sea-lion, and if circumstances permitted, he was asked a further set of questions with reference to the specific picture selected.

These were:

Q3. Where did you see this?

$Q 4$. When did you see this?

Q5. How many did you see?

Q6. What size was it?

Q7. What colour was it? 
Depending on the degree of difficulty there was communicating with the interviewee, it was sometimes possible to enter into further discussions. We attempted to ask if the animal had hair or scales and if it breathed when it came to the surface. If a monk seal had been selected, we also asked several respondents to compare the selected animal with the harbour seal and the sea-lion and to confirm that the animal they had seen was more like the monk seal than anything else. In all cases, even if a monk seal picture had not been selected from the picture board, a photograph of an Hawaiian monk seal, showing no white belly, was also shown to the interviewees at the end of the questionnaire. If the interviewee recognized it then Q3 to Q7 were asked with reference to this photograph.

In Jamaica and Haiti, interviews were conducted in English and French, respectively. Additional informal enquiries made in previous years in Cuba, the Dominican Republic and Haiti were conducted in Spanish and Creole as appropriate.

\section{Results}

Based on reports obtained from fishermen during the cruise in 1996, which indicated the possible presence of monk seals in northern Haiti, this survey concentrated on northern Haiti in 1997 and used northern Jamaica as a control. All but one of the 93 people questioned in the whole survey claimed to be fishermen (in all cases these were subsistence fishermen). The great majority (87-96 per cent) of respondents selected the four species groups (dolphin, shark, barracuda, sea turtle) that we would have expected them to have observed. Only 2 per cent $(n=2)$ selected a walrus, which is most unlikely to occur in the Caribbean; in one of these cases, it was suspected that it had been confused with another seal or even a manatee. Four percent $(n=4)$ of respondents selected a harbour seal and the same proportion selected a sea-lion. The manatee was selected by 19 per cent $(n=18)$ of respondents and the monk seal was selected by 23 per cent $(n=21$; Figure 1$)$.
In general, the response from fishermen questioned in Jamaica and Haiti was similar except that a greater proportion had seen manatees in Jamaica than in Haiti and more had seen monk seals in Haiti than in Jamaica (Figure 1).

The proportion of respondents selecting a monk seal was not significantly different from the proportion selecting a manatee (normal approximation to the binomial distribution, $t=0.365, P>0.1)$. However, the proportion selecting a monk seal was significantly greater than the proportion selecting the walrus $(t=4.22, P<0.001)$, harbour seal $(t=3.67$, $P<0.001)$ or sea-lion $(t=3.67, P<0.001)$ but less than the proportion selecting the dolphin, shark, barracuda or sea turtle $(t>8.8$, $P<0.001$ in all cases). A Monte Carlo simulation, which randomized the selection procedure, involving those individuals that had selected at least one of the pinnipeds, showed that the probability of the observed frequency distribution of pinnipeds occurring by chance was $<0.0001$.

The sea turtle was the species most frequently chosen first, followed by the barracuda, the shark and the dolphin. Other marine mammals were never chosen first or second (Figure 2). There was a significant negative relationship between the proportion of respondents choosing a particular species group and the mean selection number of each species group $\left(r^{2}=0.762\right)$. This suggests that the sequence in which a species group was selected reflected the respondent's familiarity with that group. Assuming that selection number followed a Poisson distribution, there was no significant difference between the selection number of the monk seal and the manatee $(P>0.1)$ but that number was significantly greater than for the dolphin, shark, barracuda and sea turtle ( $P<0.01$ in all cases).

In cases where the monk seal or harbour seal was selected, most respondents were questioned further. When asked when they had seen the animal, 75 per cent (18 of 24) of respondents answered 'this year' or 'last year'. The furthest back that any individual could recall seeing a seal was 10 years. This was a Jamaican fisherman who had apparently seen 
Figure 1. Frequency with which each species was selected from the range presented to fishermen in Jamaica and Haiti. The frequency combining the results from Jamaica and Haiti is also shown.

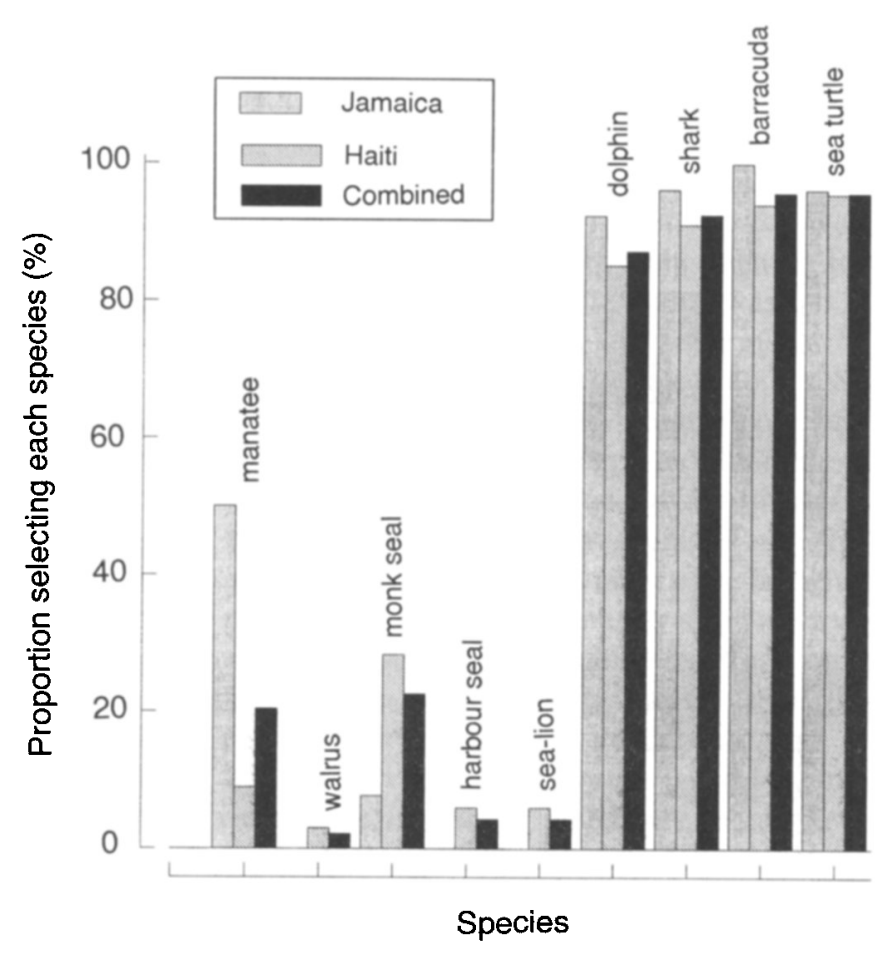

two indicated that the size varied from the size of a child to the size of a man. One fisherman indicated that the animal he had caught in a fishing net was the size of a small child. In one location, five fishermen indicated that they actively hunted monk seals when they had the opportunity, usually with spear guns. In these cases we asked what type of surface the animal had and all indicated that the surface was hair. These fishermen also said that the animals returned to the surface to breathe.

On three occasions we rejected the fisherman's selection of the monk seal or the harbour seal because, on further questioning, two fishermen thought that the harbour seal was a catfish and another thought the monk seal was a Moray eel. In addition, one individual that selected a walrus called it a 'sea cow'. These selections were not included in the above analysis. 

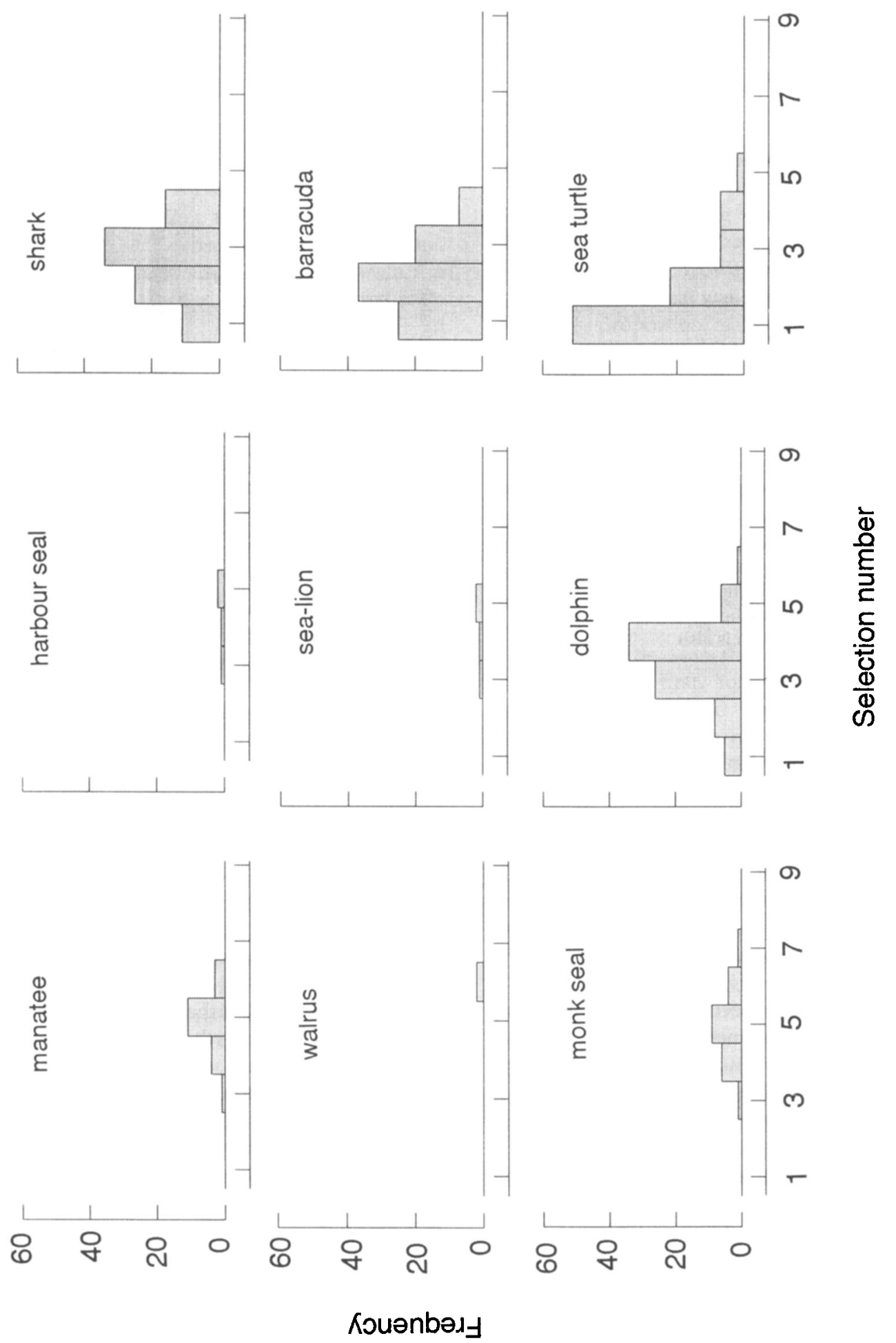


\section{Discussion}

Questioning inhabitants about the wildlife in their local environment could lead to misleading conclusions. In this study, we can be certain that fishermen did not know the purpose of the questionnaire in advance. The questionnaire was also structured to try and eliminate potential bias due to respondents intentionally deceiving the questioner. Most of the people questioned were extremely poor, almost certainly illiterate and survived in isolated villages on subsistence fishing, either from open rowing boats or by diving. We received no information to suggest that there was any intentional deception or that the respondents had misinterpreted any of the questions put to them.

The results of this study suggest that fishermen in northern Haiti and, to a lesser degree, in north-east Jamaica, see seals regularly. This is within the apparent historical range of the species (Timm et al., 1997). These reports indicate that large phocid seals, probably from the subfamily Monachinae, are regularly sighted by fishermen in the areas surveyed. The most likely explanation of these sightings is that they are of Caribbean monk seals, but the presence of other species in the area cannot be discounted. We can be reasonably certain of this because fishermen chose the animals that are known to occur commonly in the vicinity of Jamaica and Haiti with greatest frequency whereas, in general, they rejected animals that we would not have expected them to see. The frequency of selection of the monk seal was significantly $(P<0.001)$ greater than for the animals that were not expected to have been seen. Moreover, the fishermen chose the monk seal with the same frequency as they chose the manatee, a species that is known to occur in these waters (Rathbun et al., 1985), even if it is not common. The significant difference between the frequency with which the monk seal and the harbour seal were selected is potentially revealing because this suggests that the identification was specific to the monk seal or some very similar looking species. The descriptions of the size of the animals seen by respondents also suggested that juveniles were being observed occasionally. Descriptions of colour suggest that the pelage of these seals was similar to that of the other species of monk seals. The size and colour of the seals conform to the type specimen of Monachus tropicalis in the British Museum and other descriptions summarized by King (1956).

Based on the results of this study, the average sighting frequency for fishermen in the area where monk seals may occur was c. 0.19 seals per fisherman year. The fishermen who were most likely to have observed monk seals were those who mainly used diving to capture fish or shellfish. This suggested that monk seals are rarely seen at the surface or, when they are, they were rarely recognized as such.

The area identified by this survey as being potentially important for monk seals is virtually the same as that identified by Woods and Hermanson (1987). We consider that the coastal region from Port de Paix to Môle St Nicolas and Ile de La Tortue (especially the north coast), both of which are in northern Haiti, is likely to provide suitable habitat for monk seals. Much of the coastline is formed of coral limestone with numerous deep caves and wave-cut platforms. Positive responses were obtained from fishermen throughout this region.

Woods and Hermanson (1987) reported that only two of 77 people interviewed in this area in 1985 had seen a seal. There are several possible reasons for the difference between our results and those of Woods and Hermanson. These include: (i) the concentration in the current survey on fishermen, whereas Woods and Hermanson included people with a wider range of backgrounds, including coastal residents and seamen as well as fishermen; (ii) whereas our survey was conducted in a similar manner in that pictures were used, we offered the fishermen familiar subjects to help them become comfortable with the methodology and adjust their judgement to the method of presentation of the images; or (iii) the frequency with which monk seals are sighted in the area has increased in the past 12 years. However, the frequency of sightings of manatees has declined because Woods and Hermanson (1987) found 66 per cent of 
respondents had seen manatees. This compares with only 10 per cent of those questioned in northern Haiti in the present study.

Woods and Hermanson (1987) concluded that 'a remote possibility continues to exist that the Caribbean monk seal is not extinct'. Ours is the first systematic survey to suggest the continued existence of monk seals, or a specios looking very similar to monk seals, in the West Indies. As we have shown from the sighting frequencies estimated for resident fishermen, the methodology used by other surveys (Kenyon, 1977; Nichols et al., 1980; LeBoeuf et al., 1986) was most unlikely to have provided a sighting of a monk seal. Although Solow (1993) suggested there was a c. 0.05 probability that the Caribbean monk seal was not extinct, our analysis suggests the probability is much greater, based on the comparison with control species (walrus, harbour seal, sea-lion).

\section{Acknowledgements}

Many people dedicated themselves to this project through significant hardships. We are grateful to Professor Uwe Ackerman, Comdr Frank Brown RN ret., Dr Karen Gardiner, Dr Mike Hart, William Jameson, Ian Rees, Miles Sutherland Pilch, Bridget Simpson, Charlie Stanfield and Andy Wilson. We are especially grateful to Dr Mike Hart who cured the sick and who provided critical support to see us through the most important part of the survey; Professor Uwe Ackerman and Ian Rees for their unparalleled crewmanship and unstinting faith in the project; and Dr Karen Gardiner for important support during the early stages of the expedition. We thank Professor John Harwood and Dr John Croxall for comments on the manuscript.

\section{References}

IUCN. 1996. 1996 IUCN Red List of Threatened Animals. IUCN, Gland, Switzerland.

Kenyon, K.W. 1977. Caribbean monk seal extinct. Journal of Mammalogy, 58, 97-98.
King, J.E. 1956. The monk seal (Genus Monachus). Bulletin of the British Museum of Natural History, 3, 201-256.

LeBoeuf, B.J., Kenyon, K.W. and Villa-Ramirez, B. 1986. The Caribbean monk seal is extinct. Marine Mammal Science, 2, 70-72.

Nichols, G., Campbell, D. and Sargent, D. 1980. Expedition of $R / V$ Regina Maris to search for Caribbean monk seals in the southeast Bahama Islands, April 13-26, 1980. Unpublished Report to World Wildlife Fund.

Reijnders, P., Brasseur, S., Van der Toorn, J., Van der Wolf, P., Boyd, I., Harwood, J., Lavigne, D. and Lowry, L. 1993. Seals, Fur Seals, Sea Lions, and Walrus: Status Survey and Conservation Action Plan. IUCN, Gland, Switzerland.

Rathbun, G.B., Woods, C.A. and Ottenwalder J.A. 1985. The manatee in Haiti. Oryx, 19, 234-236.

Rice, D.W. 1973. Caribbean monk seal (Monachus tropicalis). Proceedings of a working meeting of seal specialists on threatened and depleted seals of the World. International Union for the Conservation of Nature and Natural Resources, Gland, Switzerland.

Solow, A.R. 1993. Inferring extinction from sighting data. Ecology, 74, 962-964.

Timm, R.M., Salazar, R.M. and Peterson, A.T. 1997. Historical distribution of the extinct tropical seal, Monachus tropicalis (Carnivora: Phocidae). Conservation Biology, 11, 549-551.

Waller, G. 1996. Sealife. A Complete Guide to the Marine Environment. Pica Press, Robertsbridge, East Sussex.

Woods, C.A. and Hermanson, J.W. 1987. An investigation of possible sightings of Caribbean monk seals, (Monachus tropicalis), along the north coast of Haiti. Report to US Marine Mammal Commission, contract number MM3309519-2, 10pp.

I. L. Boyd, Seamark Trust, 165 Woodstock Road, Oxford OX2 7NA, UK. Address for correspondence: British Antarctic Survey, Natural Environment Research Council, Madingley Road, Cambridge CB3 0ET, UK. e-mail: i.boyd@bas.ac.uk

M. P. Stanfield, Seamark Trust, 165 Woodstock Road, Oxford OX2 7NA, UK.

Received 12 January 1998

Accepted 20 July 1998 